\title{
Effect of Soil Boron Application on Flower Bud and Leaf Boron Concentrations of Olives
}

\author{
M.A. Rodrigues and M.M. Arrobas \\ Centro de Investigação de Montanha - E.S. Agrária, 5301-855 Bragança \\ Portugal
}

Keywords: boron fertilization, boron mobility, Olea europaea

\begin{abstract}
In this work we report the effect of soil boron application on flower bud and leaf mineral composition of olives. Two field experiments were carried out. For experiment 1, we selected ten pairs of olive trees, chosen from ten different olive orchards, half being cv. Santulhana and the other cv. Madural. On each pair, one tree was B-fertilized $(+B)$ on 29 March 2003 with $8.3 \mathrm{~g}$ of $B$ (as Borax, $11 \% \mathrm{~B})$ and the other pair kept as control (-B). On the experiment 2 , three trees per treatment of cv. Cobrançosa were subjected to soil application of $0,2.8,5.5,11.0$ and $22.0 \mathrm{~g}$ of $\mathrm{B}$ per tree. Flower bud samples were taken on 24 May 2003 and leaf samples on 12 July 2003 and 31 January 2004. In experiment 1 , soil B applications increased B content on flower bud. However, the differences were statistically significant $(\alpha<$ 0.05) only when the ten pairs of trees (both cv.) were jointly analyzed. Mean flower bud B contents rose from 22.3 to $24.5 \mathrm{mg} \mathrm{kg}^{-1}$. Soil B application also increased leaf $B$ content in Jul. 2003 and Jan. 2004. In experiment 2, soil B application significantly increased flower bud and leaf $B$ contents. Tissue $B$ contents ranged from 11.4 to 20.2 $\mathrm{mg} \mathrm{kg}$, 15.5 to $21.0 \mathrm{mg} \mathrm{kg}^{-1}$ and 14.0 to $16.5 \mathrm{mg} \mathrm{kg}^{-1}$, in flower buds and leaves on Jul. 03 and Jan. 04, respectively. Soil $B$ applications did neither influence the $N$, $P$, $\mathrm{K}, \mathrm{Ca}$ and $\mathrm{Mg}$ content of tissues in experiments 1 nor 2 . Flower buds seem to have had access to the recently soil applied B. Leaves and flower buds developing simultaneously seem to be concurrent sinks for recently uptaken B. Early spring soil $B$ application was effective to supply flower buds and leaves $B$ requirements during anthesis.
\end{abstract}

\section{INTRODUCTION}

Low soil boron availability is a fertility problem in vast areas of world. However, $\mathrm{B}$ requirements differ among plant species. Dicots have higher B requirements compared to monocots (Asad et al., 2001), with olives being considered high demand plants for this nutrient (Fernández-Escobar, 2001). The deficiency symptoms appear in young tissues, such as growing tips, young leaves and developing fruits (Scott et al., 1943). In Central and North Portugal inland regions, B is probably the most determinant element in olive growing. The appearance of visible symptoms is not uncommon in these regions, although that implies an extreme deficiency. Thus, we suspect that many orchards, mainly traditional non-irrigated orchards accounting for more than $90 \%$ of total area, could be managed under hidden hunger, limiting crop growth and yield. On the other hand, leaf analysis is not yet a regular practice among olive growers. While soil B shortage is currently a well-known problem, many doubts arise about B application rates, time and methods and its real effect on olive yield.

The B mobility within crop tissues has been widely study in recent years. Species seem to differ greatly in their ability to retranslocate B within the plant (Brown and Shelp, 1997). However, there is a lack of information on B mobility in olive tissues. Delgado et al. (1994) results' seem to support an apparent B retranslocation from young leaves to flower buds, but the typical symptomatology of B deficiency in olives suggest great B immobility. From a practical point of view, the question of boron retranslocation on crop tissues is extremely important to diagnose the B nutritional status of trees and to define the better strategy for supplying boron (Brown and Shelp, 1997). A shortage of B can severely limit olive yields, affecting key steps such as flowering, fruit set and shoot 
growth. With this work we intend to make a small contribution on the subject.

\section{MATERIAL AND METHODS}

The trials were carried out at Macedo de Cavaleiros, NE Portugal, on traditional non-irrigated olive orchards, with 120 to 150 mature trees per hectare. The orchards are implanted on schist derived Leptosols, in slopes varying between 2 and $6 \%$. Soil organic matter and $\mathrm{pH}\left(\mathrm{H}_{2} \mathrm{O}\right)$ of the orchards included in these experiments range between 8 and $12 \mathrm{~g} \mathrm{~kg}^{-1}$ and 5.4 and 6.4, respectively. The mean annual rainfall reaches $600 \mathrm{~mm}$. The mean monthly temperatures in January and July, the colder and warmer months, are 5.5 and $22.6^{\circ} \mathrm{C}$, respectively. Conventional tillage is the weed control method. Past fertilizations usually include soil application of small annual amounts of $N$ (10 to 30 $\mathrm{kg} / \mathrm{ha}$ ) and $\mathrm{P}$ and $\mathrm{K}$ (5 to $15 \mathrm{~kg} / \mathrm{ha}$ ). Two years after the trial starts, approx. $6 \mathrm{~g}$ of B (as borax, $11 \%$ of B) per tree had been applied on orchards of experiment 1 (hereunder described). Leaf B concentration before the trial starts (January 2003) varied between 11.3 and $17.8 \mathrm{mg} \mathrm{kg}^{-1}$, values in the deficiency range usually reported for this crop (Fernández-Escobar, 2001).

In this work one reports the effect of olive trees' soil boron application on flower bud and leaf mineral composition based upon two field trials. For experiment 1 we selected ten pairs of olive trees, from ten different olive orchards, half being cv. Santulhana and the other cv. Madural. Each pair was made of two neighbouring trees with similar canopies. On each pair, one tree was B-fertilized (+B) on 29 March 2003 with 8.3 $\mathrm{g}$ of $\mathrm{B}$ (as borax) and the other pair kept as control (-B). On experiment 2, three trees per treatment of cv. Cobrançosa were subjected to soil application of $0,2.8,5.5,11.0$ and $22.0 \mathrm{~g}$ of B per tree. Tissue samples were individually taken from each tree. Just prior to flowering, full developed flower buds were taken on 24 May 2003. The leaves were selected from the middle portion of one-year shoots on 12 July 2003 and 31 January 2004. The samples were dried $\left(70^{\circ} \mathrm{C}\right)$ and ground. Tissue analyses were performed by Kjeldahl $(\mathrm{N})$, colorimetry $(\mathrm{B}$ and $\mathrm{P})$, flame emission spectrometry $(\mathrm{K})$ and atomic absorption spectrometry ( $\mathrm{Ca}$ and $\mathrm{Mg}$ ) methods (Walinga et al., 1989).

Mean confidence limits $(\alpha<0.05)$ were estimated to compare the dots populations of experiment 1 . The analysis of variance was performed for data of experiment 2 , being the means separation made by Tukey HSD test $(\alpha<0.05)$.

\section{RESULTS}

\section{Experiment 1}

Soil B applications increased B content on flower bud, although the means difference was not significant $(\alpha<0.05)$. Boron content on flower bud rose from 22.6 to $25.4 \mathrm{mg} \mathrm{B} \mathrm{kg}{ }^{-1}$ on cv. Santulhana and from 21.9 to $23.7 \mathrm{mg} \mathrm{B} \mathrm{kg}^{-1}$ on cv. Madural. The mean difference was significant when jointly analyzing the ten pairs of samples (Fig. 1). Mean leaf B concentration in July increased with B application for cv. Santulhana and for cv. Madural (Fig. 2). Leaf B concentrations rose from 23.0 to $26.2 \mathrm{mg} \mathrm{kg}^{-1}$ and from 19.8 to $22.7 \mathrm{mg} \mathrm{kg}^{-1}$ with $\mathrm{B}$ application, respectively. As recorded for flower buds, the mean differences were only significant when jointly analyzing the ten pairs of trees. In January 2004, leaf B concentrations were kept higher on $+B$ trees (Fig. 2), though globally lower than in the previous summer. Soil B applications did not significantly influence the N, P, $\mathrm{K}, \mathrm{Ca}$ and $\mathrm{Mg}$ status of trees (data not shown).

\section{Experiment 2}

Flower bud B concentrations significantly increased with soil B application (Table 1). The values varied from $11.4 \mathrm{mg} \mathrm{kg}^{-1}$ in the control to $20.2 \mathrm{mg} \mathrm{kg}^{-1}$ when $11.0 \mathrm{~g}^{\text {of B }}$ per tree were applied. Soil B application in early spring of 2003 had also a statistically significant effect on leaf B concentration in July 2003 (values varying from 15.5 to 21.0 $\mathrm{mg} \mathrm{B} \mathrm{kg}{ }^{-1}$ ) which persisted in January 2004, although with a lower range of variation (14.0 to $16.5 \mathrm{mg} \mathrm{B} \mathrm{kg}^{-1}$ ) (Table 1). As recorded in experiment 1, soil B application didn't 
have any detectable effect on mineral composition of flower buds and leaves, excluding the B content of tissues (data not shown).

\section{DISCUSSION}

The orchards used in this study reveal lower tissue B contents compared to standard adequate critical ranges reported for this crop (Fernández-Escobar, 2001). Soils are shallow, coarse textured, acids or slightly acids and have low organic matter contents, conditions usually associated to low soil B availability (Offiah and Axley, 1993).

Flower buds seem to have had access to the recently applied B. Delgado et al. (1994) reported a B decrease on young leaves during anthesis. The authors considered that B remobilization for flower buds was the reason for the B decrease in young leaves. Evidence of $\mathrm{B}$ retranslocation from leaves to other tissues was also reported by Perica et al. (2002). However, our results suggest that the B found in the flower buds could also be recently taken up B. The decrease of B content in the growing young leaves certainly was due to the high demand for available B in flower buds, since these represent the primary carbohydrate sink in this period. However, growing leaves and flower buds seem to be concurrent sinks for recently taken up B. In addition, early spring soil B application was effective to supply flower buds and leaves B requirements during anthesis.

\section{ACKNOWLEDGEMENT}

We thank Rita Diz and Ana Pinto for laboratorial assistance. The financial support was provided by Portuguese Department of Agriculture, Rural Development and Fisheries and European Union through the project PO AGRO, DE \& D, No 743.

\section{Literature Cited}

Asad, A., Bell, R.W. and Dell, B. 2001. A critical comparison of the external and internal boron requirements for contrasting species in boron-buffered solution culture. Plant and Soil 233: 31-45.

Brown, P.H. and Shelp, B.J. 1997. Boron mobility in plants. Plant and Soil 193: 85-101.

Delgado, A., Benlloch, M. and Fernández-Escobar, R. 1994. Mobilisation of boron in olive trees during flowering and fruit development. HortScience 29 (6): 616-618.

Fernández-Escobar, R. 2001. Fertilization. p. 255-284. In: D. Barranco, R. FernándezEscobar and L. Rallo (eds.), El Cultivo del Olivo, $4^{\text {th }}$ Ed., Mundi-Prensa and Junta de Andalucia, Madrid.

Offiah, O.O. and Axley, J.H. 1993. Soil testing for boron on acid soils. p. 105-123. In: U.C. Gupta (ed.), Boron and its Role in Crop Production, CRC Press, Florida.

Perica, S., Brown, P.H., Connell, J.H. and Hu, H. 2002. Olive response to foliar boron application. Acta Hort. 586: 381-383.

Scott, C.E., Thomas, H.E. and Thomas, H.E. 1943. Boron deficiency in the olive. Phytopathology 9 (3): 933-942.

Walinga, I., van Vark, W., Houba, V. and van der Lee, J. 1989. Soil and Plant Analysis. Part 7 - Plant analysis procedures, Wageningen Agric. Univ., The Netherlands. 


\section{Tables}

Table 1. Soil B application effect on flower bud and leaf B concentrations. In each column, the mean values with the same letter are not statistically different by Tukey HSD test $(\alpha<0.05)$.

\begin{tabular}{lccc}
\hline & \multicolumn{3}{c}{ B content $\left(\mathrm{mg} \mathrm{kg}^{-1}\right)$} \\
\cline { 2 - 4 } B applied $(\mathrm{g}$ /tree $)$ & Flower bud & Leaf $(\mathrm{Jul} \mathrm{03})$ & Leaf $($ Jan 04) \\
\hline 0 & $11.4 \mathrm{~b}$ & $15.5 \mathrm{~b}$ & $14.0 \mathrm{ab}$ \\
2.8 & $10.4 \mathrm{~b}$ & $16.7 \mathrm{ab}$ & $13.3 \mathrm{~b}$ \\
5.5 & $14.2 \mathrm{~b}$ & $18.7 \mathrm{ab}$ & $14.5 \mathrm{ab}$ \\
11.0 & $20.2 \mathrm{a}$ & $21.0 \mathrm{a}$ & $16.5 \mathrm{a}$ \\
22.0 & $19.7 \mathrm{a}$ & $19.7 \mathrm{a}$ & $16.0 \mathrm{ab}$ \\
\hline
\end{tabular}

\section{Figures}

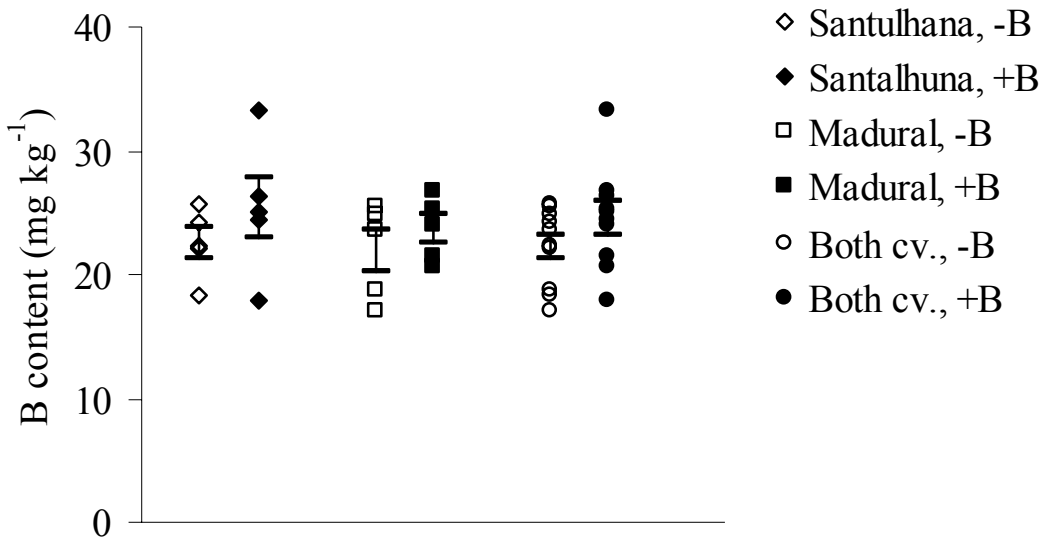

Fig. 1. Flower bud boron content on 24 May 2003, just before blossom. +B treatments consisted on soil application (29 March 2003) of $8.3 \mathrm{~g}$ of B (as borax, 11\% of B). Vertical bars are the mean confidence limits.

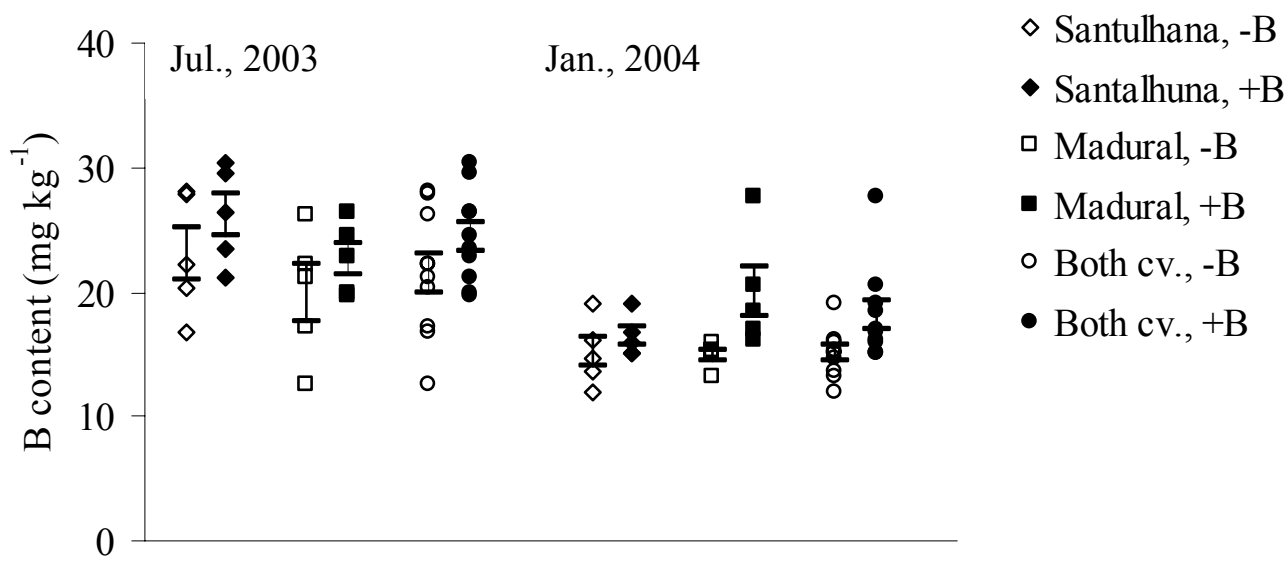

Fig. 2. Leaf boron content on 12 July and 31 January. $+\mathrm{B}$ treatments consisted on soil application (29 March, 2003) of $8.3 \mathrm{~g}$ of B (as borax, 11\% of B). Vertical bars are the mean confidence limits. 